
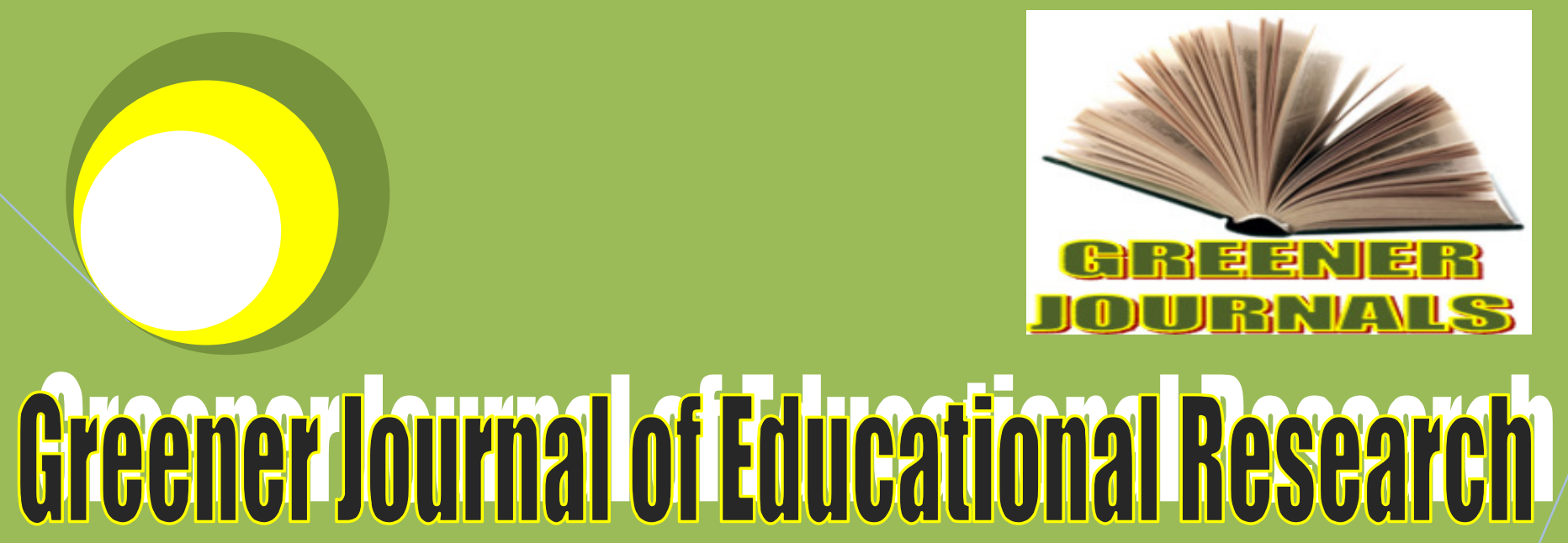

ISSN: 2276-7789 Impact Factor 2012 (UJRI): 0.7230 ICV 2012: 6.05

Search for Quality

Assessment in Open

and Distance Learning

at Undergraduate

Level Teaching

Practice at the

Zimbabwe Open

University

By

Augustine Kudakwashe Mubika Barnabas Muyengwa 


\title{
Search for Quality Assessment in Open and Distance Learning at Undergraduate Level Teaching Practice at the Zimbabwe Open University
}

\section{${ }^{1}$ Augustine Kudakwashe Mubika, ${ }^{\star 2}$ Barnabas Muyengwa}

\author{
${ }^{1}$ Senior Lecturer and Regional Programme Co-ordinator for the Mashonaland West Regional Centre of the Zimbabwe \\ Open University: Department of Education. \\ ${ }^{2}$ Lecturer and National Programme Leader for the Bachelor of Education (Secondary), Bachelor of Education \\ (Curriculum Studies) and Post Graduate Diploma in Education (PGDE) at the Zimbabwe Open University. \\ 1Email: akmubika@gmail.com
}

*Corresponding Author's Email: muyengwabb@gmail.com

\begin{abstract}
Teaching at a distance is a new phenomenon in Zimbabwe. Many questions seem to be raised by academic pundits each time they hear the mention of teacher education by Open and Distance Learning. Some tend to question the quality of the products, while others appear to raise doubt about the credibility of the qualifications. This paper focuses on interrogating ways of enhancing the search for quality assessment in Open and Distance Learning at undergraduate level Teaching Practice at the Zimbabwe Open University. Research participants included District Education Officers, school heads, prospective students and academic members of the Department of Education. These were purposely sampled. Data were analysed using textual analysis that enabled the researchers to come up with themes which paved way to data analysis. Results of study showed that teaching practice is an essential component of any teacher education programme at diploma level. It was observed that teaching practice is underfunded.There is also need to pay attention to critical components such as teaching practice, professional studies, theory of education and main study. It is further recommended that teaching practice should be fully funded. All stakeholders should be involved in the external assessment of teaching practice.
\end{abstract}

Keywords: Quality Assessment, Open and Distance Learning, Undergraduate Level Teaching Practice.

\section{INTRODUCTION}

Open and Distance Learning (ODL) has had numerous challenges most of which are not commonly experienced in conventional institutions. This has led in some cases to problems of acceptance of its products. One such case is the acceptance of teachers trained through ODL. A major factor contributing to acceptance problems is the issue of Teaching Practice (TP). For example, when the Zimbabwe Council for Higher Education (ZIMCHE) suspended the Zimbabwe Open University's (ZOU) Diploma in Education (Primary) one of the cited major reason for suspension was lack of supportive materials and supervision while students are on teaching practice (ZIMCHE letter of 20 October 2011). The focus of this paper is to interrogate ways and means of enhancing the search for quality assessment in Open and Distance Learning at undergraduate level Teaching Practice at the Zimbabwe Open University (ZOU).

\section{BACKGROUND TO THE STUDY}

Teaching Practice is evidently a very important component in teacher education. As such, it must be well organized in terms of content, implementation and assessment. Teaching practice ensure that the student teacher acquires practical hands on experience of what happens in the classroom as well as school situation and the entire education system. It facilitates the meaningful marrying of theory and practice as opposed to decontexualised learning that characterises many teacher development programmes (Fullan and Hargreaves, 1996, cited in Bertram, Foteringham\& Harley, 2000). 
There is need to look how the issues of content, implementation and assessment are catered for in the Diploma in Education (Primary) at the ZOU. Critical in this regard is the Teaching Practice (TP) departmentfor the coordination of all teaching practice activities. ZOU being an ODL institution has lecturers trained in different settings and through different modes, there is bound to be the existence of a diversity of ways in the assessment of students on teaching practice. Consequently, the TP department of necessity has to come up with policy guidelines on teaching practice that are standard and to be adhered To by all Regional Programme Coordinators and tutors. All the assessment instruments should be generated from this TP department, of course with the input of the coordinators and tutors who are in the regions.While on teaching practice, there is need for collaboration among the stakeholders who are the school, the training institution and the Ministry of Education in the supervision and assessment of teaching practice. It is therefore of interest to this study to find out the ways and means of enhancing quality assessment of the teaching practice of the Diploma in Education (Primary) at the ZOU.

\section{Statement of the Problem}

Assessment of teaching practice is usually characterized by problems that would militate against practical aspects of quality teaching.It is against this background that this study focusses on finding out the means and ways of how the issues of content, implementation and assessment of teaching practice are catered for in the Diploma in Education (Primary) at the ZOU. The main question of this study is: To what extent are the issues of content, implementation and assessment of teaching practice are looked into with regard to Diploma in Education at the ZOU?

\section{RESEARCH QUESTIONS}

In an effort to answer the main research question, the following sub-problems which stand as research sub-questions suffice:

- What is the importance of teaching practice in teacher education at diploma level?

- How is teaching practice organized at the ZOU?

- How is teaching practice supervised at school level?

- Who assesses students' teaching practice internally?

- Who are the teaching practice external assessors?

\section{Significance of the Study}

This study is significant in many ways. Firstly, its provision of empirical evidence would assist in convincing stakeholders on the importance of teaching practice in teacher education in ODL. Secondly, the study would clearly show how teaching practice is organized at the ZOU. Thirdly, it would evidently generate information about how teaching practice is supervised at school level. Fourthly, it would also clarify who is involved in internal assessment of teaching practice at the ZOU. Furthermore, it would show who is involved in external assessment of teaching practice at the ZOU.

\section{Review of Related Literature}

\section{What is Teaching practice?}

Teaching practice is the time spent by a student teacher in a school gaining practical teaching experience. The teaching by the student teacher is done under the supervision of an experienced teacher. The experienced teacher acts as a mentor for the student teacher. Learning to teach is enhanced when it is more like a team effort than a solo race. Good learning, like good work, is collaborative and social, not competitive and isolated. Working with others often increases involvement in learning to teach. 


\section{Principles of Good Teaching Practice}

Teachers are responsible and accountable for designing and delivering a high quality of learning and teaching practice. Good teaching practice is a key influence on student learning - a desired outcome and primary goal of higher educational institutions. Teachers strive to meet the principles of good practice in an effort to provide the best learning experience for their students. According to Chickering and Ehrmann (1996) principles of good teaching practice include some of the following:

\section{Good practice encourages interaction between students and faculty.}

Frequent student-faculty contact in and out of class is a most important factor in student motivation and involvement. Faculty concern helps students get through rough times and keep on working. It also enhances students' intellectual commitment and encourages them to think about their own values and plans.

\section{Good practice encourages interaction and collaboration between students.}

Team effort is essential in teaching practice hence it brings about collaborative learning. The fact that collaborative learning by nature and character is social cannot be over emphasized. In essence, it is important to share one's ideas as well as responding to others since this improves thinking and also deepens understanding of issues

\section{Good practice uses active learning techniques.}

Learning is not a spectator sport. Students do not learn much just sitting in classes listening to teachers, memorizing prepackaged assignments, and spitting out answers. They must talk about what they are learning, write reflectively about it, relate it to past experiences, and apply it to their daily lives. They must conceptualize what they learn.

\section{Good practice gives prompt feedback.}

Knowing what you know and don't know focuses your learning. In getting started, students need help in assessing their existing knowledge and competence. Then, in classes, students need frequent opportunities to perform and receive feedback on their performance. At various points during college, and at its end, students need chances to reflect on what they have learned, what they still need to know, and how they might assess themselves.

\section{Good practice emphasizes time on task.}

Time plus energy equals learning. Learning to use one's time well is critical for students and professionals alike. Allocating realistic amounts of time means effective learning for students and effective teaching for faculty.

\section{Good practice communicates high expectations.}

Expect more and you will get it. High expectations are important for everyone - for the poorly prepared, for those unwilling to exert themselves, and for the bright and well motivated student. Expecting students to perform well becomes a self-fulfilling prophecy.

\section{Good practice respects diversity --- talents, experience, and ways of learning}

Many roads lead to learning. Different students bring different talents and styles to college. Brilliant students in a seminar might be all thumbs in a lab or studio; students rich in hands-on experience may not do so well with theory. Students need opportunities to show their talents and learn in ways that work for them. Then they can be pushed to learn in new ways that do not come so easily.

\section{Organisation of teaching practice}

The Department organizes students' teaching practice and provides guidance. "A Guide to Teaching Practice" has long been a major standard for all students on initial teacher training courses (Cohen and Manion, 2002). The guide should take into account of the many changes which have taken place both within the education system and within training courses, including: school-based training, the impact of information technology and the increasing concern for school effectiveness. The important basic skills and issues which students need to consider during their practice, such as planning, classroom organisation, behaviour management and assessment.

In the organisation of teaching practice, supervision by the university and school based staff takes place throughout the duration of teaching practice. The current study attempts to look at the extent to which this is done at the ZOU. It is interesting to further acknowledge that teaching practice supervision is a collaboration among the stakeholders who include the school, the training institution and the Ministry of Education. ZOU also directs that a 
teaching practice file shall be kept by all student teachers and this should have the syllabi, schemes of work, classroom timetable, lesson plans, mark lists/progress records, social records, remedial records, inventory lists, lesson notes and observation crits, among other documents. It is important to also recognize that teaching practice for ZOU's open and distance learning students, teaching practice is carried out for entire duration of the course.

\section{School based supervision of teaching practice}

Supervised teaching practice is practical supervision of teaching under the tutelage of an established teacher in a school. In other words, the student operates under the guidance of a mentor. Mentoring is a key strategy for assisting beginning teachers to successfully navigate their way into the profession (Pitton, 2006). Having a mentor should advance beginning teachers far beyond what they could achieve unaided (Freeman, 2002). It is proposed as a costeffective integrated approach to linking the support and development of teachers with quality assurance. Supervision saves a number of purposes in the professional growth of a teacher. Besides the quality assurance aspect, supervision ensures that the student teacher acquires the correct base line skills of teaching and class management. According to Kadushin's (1992) model of supervision, the functions of supervision are in the following terms:

Administrative the promotion and maintenance of good standards of work, co-ordination of practice with policies of administration, the assurance of an efficient and smooth-running practice;

Educational - the educational development of each individual worker on the staff in a manner calculated to evoke her fully to realize her possibilities of usefulness; and

Supportive the maintenance of harmonious working relationships.

This study also focuses on finding out how teaching practice is supervised at school level.

\section{Internal assessment of teaching practice}

Internal assessments are used to make decisions about instruction and to report progress. In teaching practice, internal assessment is done by school based supervisors and lecturers from the training institution. In the case of the ZOU, lecturers work in collaboration with school heads and senior qualified teachers in assessing students on teaching practice.

\section{External assessment of teaching practice}

External assessments are designed, selected, and controlled by another person or group. In the case of ZOU teaching practice, external assessors include Lecturers from other Universities' Faculties of Education, Teachers Colleges, and Education Officers from the Ministries of Education. External assessments occur less frequently than internal assessments, but they usually have greater importance, more authority, and higher stakes attached to them. External assessments have been used as indicators of both the educational achievement of students and the quality of instruction in schools as well for certification purposes (Green, Bell, Oates and Bramley, 2006, unpublished paper).

\section{RESEARCH METHODOLOGY}

The current study adopted the qualitative paradigm. Qualitative study is essential for the conduct of this study as it analyses information conveyed through language and behavior in natural settings (Kumar, 2008; Gray, 2009) A purposive sample is used in this study because it is a qualitative non-probability sample which is usually consistent with the needs of research studies on beliefs, values, feelings, and motivations that underlie behaviors. This study purposely sampled four District Education Officers, six heads of schools, eight prospective students from the two ZOU regions of Mashonaland East and Mashonaland West, and sixteen academic members of the Department of Teacher Development. The respondents responded to in-depth interviews to gather thick descriptions of data (Silverman, 2006). Thus, in-depth interviews have the ability to gather dense data from respondents. Seale and Charteris-Black (2006) confirms this when he points out that in-depth interviews because of their open ended nature have the capacity to gather lots of rich research data from research participants. All research participants answered the same questions so as to obtain consistent data on issues of content, implementation and assessment of teaching practice. The gathered data are qualitative, thereby, enabling the researchers to rely on words for their presentation. For demographic data of the participants, tables were used to present them, thus, giving way to data analysis and 
discussion. Data were analysed using textual analysis that enabled us to come up with themes which pave way to data analysis and discussion.

\section{RESEARCH FINDINGS}

The presentation and discussion of research findings are done in two ways. The demographic data of research participants were presented and discussed prior the interpretation of the research findings.

\section{Demographic Data}

This section covers research characteristics of the research participants who were interviewed using an in-depth interview schedule. Among other things, the demographic data reveals participants' gender, age and highest professional qualification.

Table 1: Research participants by gender ( $\mathrm{N}=34)$

\begin{tabular}{|l|c|c|}
\hline Gender & Frequency & Frequency (\%) \\
\hline Female & 11 & 32 \\
\hline Male & 23 & 68 \\
\hline Total & $\mathbf{3 4}$ & $\mathbf{1 0 0}$ \\
\hline
\end{tabular}

There were more males (68\%) than females in this study. This is consistent with the distribution of males and females in tertiary institutions.

Table 2: Research participants by age ( $\mathrm{N}=34)$

\begin{tabular}{|l|c|c|}
\hline Age in years & Frequency & Frequency (\%) \\
\hline Less than 20 & 2 & 6 \\
\hline $20-29$ & 4 & 12 \\
\hline $30-39$ & 2 & 6 \\
\hline $40-49$ & 6 & 18 \\
\hline $50-59$ & 13 & 38 \\
\hline $60-69$ & 7 & 20 \\
\hline Total & $\mathbf{3 4}$ & $\mathbf{1 0 0}$ \\
\hline
\end{tabular}

The distribution of research participants by age shows that most of the respondents are in the age group of between 50 and 59 years and they are $38 \%$. These are mainly people in posts of responsibility, for example school heads, District Education Officers and university lecturers. Then they are followed by the age group of 60 to 69 years $(20 \%)$. The least number of respondents are in the age groups of less than 20 years and between 30 and 39 with percentages of six apiece. All the respondents are mature enough to provide reliable data for this particular study.

Table 3 Research participants by highest professional qualification ( $N=34)$

\begin{tabular}{|l|c|c|}
\hline $\begin{array}{l}\text { Highest Professional } \\
\text { Qualifications }\end{array}$ & Frequency & Frequency (\%) \\
\hline PhD & 1 & 3 \\
\hline Masters degree & 23 & 68 \\
\hline Bachelors degree & 2 & 6 \\
\hline Diploma/Certificate holders & 0 & 0 \\
\hline None & 8 & 23 \\
\hline Total & $\mathbf{3 4}$ & $\mathbf{1 0 0}$ \\
\hline
\end{tabular}


Most the respondents (68\%) are masters degree holders since the majority of these are university lecturers where this is the minimum requirement for employment. There are no respondents with a highest professional qualification of a diploma or certificate since the sample comprises of lecturers, school heads, District Education Officers and potential students who are yet to be trained.

\section{DATA DISCUSSION}

This section looks into responses from the in-depth interviews carried out in this study.

\section{The importance of teaching practice in teacher education at diploma level}

In responding to the issue of the importance of teaching practice in teacher education at diploma level, the majority of the respondents appeared to appreciate the crucial role played by teaching practice in teacher education. One of the respondents who is an Education Officer said that teaching practice would be incomplete without the teaching practice component. In his view, he empathically pointed out that teaching practice provides hands on practice and opportunities to marry theory with practice in an actual classroom situation. He further pointed out that teaching practice must be assessed from time to time if it is to bring about the desired results in regards to teacher effectiveness.( Wiliam, 2006). However, one of the respondents argued to say that while she recognizes the necessity of teaching practice, her view was that it is not as important as Professional Studies. For her teaching would not achieve set objectives if, for example, one has no knowledge in effective scheming, record keeping, classroom management and assessment of pupil learning. Given these divergent views, it would appear that both respondents have strong and convincing views revealing the complimentary nature of the various components of the teacher education programme.

\section{Organisation of Teaching Practice at the ZOU}

The way the teaching practice is run at any teacher education institution determines the extent to which programme goals are realized (Cohen and Manion, 2002). In responding to the question on organisation of teaching practice at the ZOU, one of the respondents replied to say that there is need to improve on the way teaching practice is organized. His point of focus was on the issue of deployment to schools with trained mentors. In his case, he advocated for a situation where a student teacher is consistently guided by a mentor who should be a qualified teacher. In Education, mentoring is a complex and multi-dimensional process of guiding, teaching, influencing and supporting a beginning or new teacher. It is generally accepted that a mentor teacher leads, guides and advises another teacher more junior in experience in a work situation characterized by mutual trust and belief (Schatz, 2006). His second notable observation on the way teaching practice is organized at the ZOU, is that teaching practice is underfunded as there are no specific vehicles allocated for teaching practice supervision and assessment.

\section{Supervision of Teaching Practice at School Level}

Answers to this question were quite interesting in a number of ways, one of the respondents disappointedly retorted that in some incidence it is only the school head who would supervise, once in a while. This is done to the detriment of the professional growth of the student teacher who should benefit from continuous assessment at school level (Wiliam, 2006). Another respondent pointed out that the school head would only order that supervision for the purposes of writing his own report for eventual submission to his superiors. Other respondents are appreciative of the level of support they are getting from the school head and senior teachers, especially on the aspects of record keeping, class and classroom management. Such support helps students solve problems in teaching and learning; provide personal and professional support; and guide the growth of the new teacher through reflection, collaboration, and shared inquiry (Schatz, 2006)

\section{Internal Assessment of Students' Teaching Practice}

Responding to the issue of internal assessment, one of the respondents expressed disappointment on the way some of those responsible for internal assessment were carrying it out. This is so because those who are responsible for internal assessment are not doing it as it is expected as they view this task as not one of their core duties. As a result, more often than not, they go to the extent of even forgetting to assess the student who then has to remind them of this important exercise. The role of school based internal assessment in teacher education seems not to be appreciated by some key stakeholders who include school personnel, practicing students and pupils. Training 
institutions also tend to give less weight to school based internal assessment in the computation of the final grades for teaching practice. The importance of setting goals and expectations for internal assessment cannot be overemphasized (Janas,1996). Clear goals and expectations must be articulated that are specific to internal assessment and what is intended to be accomplished.

\section{External assessment of teaching practice}

The respondents expressed the need to involve more stakeholders in external assessment of teaching practice at the ZOU. They further mentioned that the student teachers do not even know who are their external assessors are. As a result, in a number of areas respondents indicated that no external assessor ever comes to externally assess them. It was also clear in their responses that this was likely to affect how people perceive the qualification they would be accorded at the end of the programme. It has to be realized that external assessments occur less frequently than internal assessments, but they usually have greater importance, more authority, and higher stakes attached to them.

\section{SUMMARY OF MAIN FINDINGS}

On the basis of the responses above, the following are the main findings of the study:

- From the responses it became abundantly clear that teaching practice is an essential component of any teacher education programme at diploma level. The study emphasizes the need to fully effect teaching practice so as to achieve desired objectives in teacher education.

- Responses also revealed the complimentary nature of the various components of the teacher education programme and therefore the need to pay attention to those various components.

- The organisation of teaching practice at the ZOU is not organized in the manner in which it should be. It was observed that teaching practice is underfunded as there are no specific vehicles allocated for teaching practice supervision and assessment.

- While other student teachers appreciate the level of support they are receiving at school level, it was revealed that some of the school personnel are not carrying out the supervision as expected.

- The role of school based internal assessment in teacher education seems not to be appreciated by some key stakeholders who include school personnel, practicing students and pupils. Clear goals and expectations that are specific to internal assessment are not articulated.

- Not all stakeholders are involved in the external assessment of teaching practice.

\section{CONCLUSIONS}

In an effort to find out the means and ways of how the issues of content, implementation and assessment of teaching practice are catered for in the Diploma in Education (Primary) at the ZOU, from the above findings the following conclusions are drawn:

- There is need to fully effect teaching practice so as to achieve desired objectives in teacher education at the ZOU.

- There is need to pay attention to those various critical components of the teacher education programme such as teaching practice, professional studies, theory of education and main study.

- Teaching practice is underfunded as there are no specific vehicles allocated for teaching practice supervision and assessment.

- It was revealed that some of the school personnel are not carrying out the supervision as expected.

- Clear goals and expectations that are specific to internal assessment are not articulated. 
- Not all stakeholders are involved in the external assessment of teaching practice.

\section{RECOMMENDATIONS}

From the above conclusions the following recommendations are made:

- Teaching practice should be fully effected so as to achieve desired objectives in teacher education at the ZOU.

- Attention should be paid to critical components of the teacher education such as teaching practice, professional studies, theory of education and main study.

- Teaching practice should be fully funded so as to have specific vehicles allocated for teaching practice, supervision and assessment.

- School personnel should carry out supervision as expected.

- Clear goals and expectations that are specific to internal assessment should be articulated.

- All stakeholders should be involved in the external assessment of teaching practice.

\section{REFERENCES}

Bertram C., Foteringham R. and Harley K., (2000). Curriculum Studies. Pietermaritzburg:UNP

Chickering A. and Ehrmann S., (1996). Implementing the Seven Principles: Technology as Lever. AAHE Bulletin: October1996:pp3-6.

Cohen L. and Manion L., (2002). A Guide to Teaching Practice. London: Routledge.

Fullan M. and Hargreaves A., (1996). What's Worth Fighting for in Your School?.New York: Teachers College Press Gray D., (2009). Doing Research in the Real World. London: SAGE Publications.

Janas D. and Dahlhaus D., (1996). A Freqency Domain Bootstrap for Statistics in Time Series Analysis. Annals of Stastics:24, 1934-1936.

Kadushin A., (1992). Supervision in Social Work. Columbia University Press.

Kumar R., (2008). Research Methodology. New Dehli: APH Publishing.

Pitton D., (2006). Mentoring Novice Teachers. London: SAGE Publications.

Schatz P., (2006). Mentor Descriptions of the Important Features in Activity Setting Mentoring. University of Southern California: ProQuest.

Seale C. and Charteris-Black J., (2006). The SAGE handbook of Qualitative Methods in Health Research. London: SAGE Publications.

Silverman D., (2006). Interpreting Qualitative Data. London: SAGE Publications.

Wiliam D., (2007/2008). Changing Classroom Practice: Educational Leadership 65(4): 36-42. 